\title{
The Essential of Entrepreneurship Inclination in Higher Learning Institution (HLI)
}

Ima Ilyani binti Ibrahim, Mohd Fazly bin Mohd Razali, Rozihana binti Shekh Zain, Mohamad Niza bin Md Nor, Ismalaili binti Ismail \& Syazwani binti Ya

To Link this Article: http://dx.doi.org/10.6007/IJARBSS/v11-i7/10553 DOI:10.6007/IJARBSS/v11-i7/10553

Received: 23 May 2021, Revised: 28 June 2021, Accepted: 18 July 2021

Published Online: 26 July 2021

In-Text Citation: (Ibrahim et al., 2021)

To Cite this Article: Ibrahim, I. I. binti, Razali, M. F. bin M., Zain, R. binti S., Nor, M. N. bin M., Ismail, I. binti, \& Ya, S. binti. (2021). The Essential of Entrepreneurship Inclination in Higher Learning Institution (HLI). International Journal of Academic Research in Business and Social Sciences, 11(7), 1677-1686.

Copyright: (C) 2021 The Author(s)

Published by Human Resource Management Academic Research Society (www.hrmars.com) This article is published under the Creative Commons Attribution (CC BY 4.0) license. Anyone may reproduce, distribute, translate and create derivative works of this article (for both commercial and non-commercial purposes), subject to full attribution to the original publication and authors. The full terms of this license may be seen at: http://creativecommons.org/licences/by/4.0/legalcode

Vol. 11, No. 7, 2021, Pg. 1677 - 1686

Full Terms \& Conditions of access and use can be found at http://hrmars.com/index.php/pages/detail/publication-ethics 


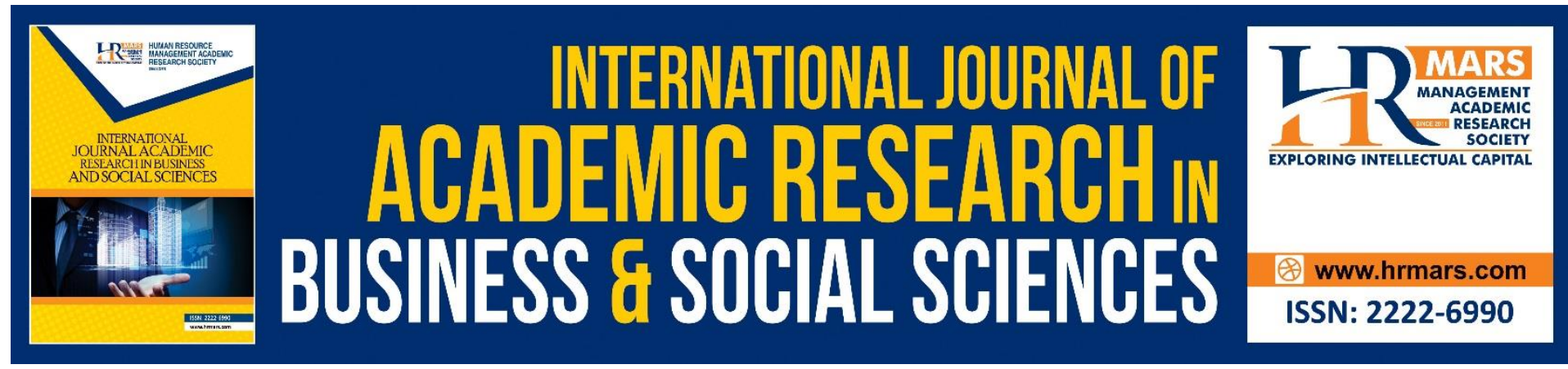

\title{
The Essential of Entrepreneurship Inclination in Higher Learning Institution (HLI)
}

\author{
Ima llyani binti Ibrahim, Mohd Fazly bin Mohd Razali, Rozihana \\ binti Shekh Zain, Mohamad Niza bin Md Nor, Ismalaili binti Ismail \\ \& Syazwani binti $\mathrm{Ya}$
}

Faculty of Business and Management, Universiti Teknologi MARA, Perlis Branch, Arau Campus, 02600 Arau, Perlis, Malaysia

Email: ilyani686@uitm.edu.my,mohdfazly@uitm.edu.my,rozihana@uitm.edu.my, mohdniza@uitm.edu.my, ismalaili007@uitm.edu.my, syazwani446@uitm.edu.my

\begin{abstract}
The Malaysia Ministry of Higher Education introduced entrepreneurship mandatory subjects to all students at the nation public universities. Universities and colleges have offered entrepreneurship programs or courses at the graduate and undergraduate levels. Even though most HLI students were taught with entrepreneur courses or programs, the entrepreneurial activities among the students are still ambiguous. This paper main objective is to investigate the relationship between role model, family background, and entrepreneurship curriculum and content with the entrepreneurial inclination. The data were collected from the Faculty of Business and Management student in Higher Learning Institution. The study indicates that all variables were proven important in explaining the inclination towards entrepreneurship. The findings will facilitate the university in developing curriculum and initiatives that align with students' goals in defining their future endeavors as entrepreneurs.
\end{abstract}

Keywords: Entrepreneurship Inclination, Role Model, Family Background, Entrepreneurship Curriculum and Content

Introduction

COVID-19, a terrible epidemic that has been wreaking havoc on people's health, social lives, and economies, is now sweeping and tremendously affecting the globe. There is a compelling need for a thorough, authoritative, and evidence-based evaluation of the pandemic's effects on entrepreneurial activity, attitudes, and goals throughout the world, including Malaysia. This scenario explains how entrepreneurial inspiration and activities differ throughout the world from the last time. Malaysia is one of the countries that make entrepreneurship as an important thing especially to the growth of Malaysian economy. Some of the evidences by the number or percentage of supporting mechanisms and policies that exist for entrepreneurs that include physical infrastructures that have been provided by the government, funding that have been given, training and as well business advisory services. Besides that, in 1995, there was an establishment of a special ministry for entrepreneurs, namely Ministry of Entrepreneur Development of Malaysia that highlighted the priority the government placed on 
entrepreneurship and entrepreneurs' development (Sandhu et al., 2011). Howbeit, total entrepreneurial activity (TEA) in Malaysia is the lowest as compared to other countries and it has been recorded in the Global Entrepreneurship Monitor (GEM) in 2010. Auspiciously, the number of the entrepreneurship activities has been increase from 4.4\% in 2009 to $4.96 \%$ in 2010, and this is the former data founded from GEM that involved Malaysia.

Seeing that entrepreneurship has been scrutinized as an importance to economic growth and progress in developing countries especially during this pandemic, some attentions have been given to the past decade of researcher on the factors that influence the intention of individual to start new businesses and particularly the entrepreneurial intentions (EIs) of those still within the education system (Karimi, 2014). Academics, policymakers, and researchers agree that entrepreneurship is a vital route to economic advancement for both developed and developing economies (Zeleamelm et al., 2004). Consequently, by introducing entrepreneurial courses to students is a resolute effort to promote entrepreneurship as well as to make it as a promising professional career and it would hopefully increases the demand from many universities and colleges around the world. Unfortunately, Malaysian government planned to increase the entrepreneurial courses in Malaysia was not success when it was proofed the number of entrepreneurs in Malaysia is still inferior and the entrepreneurial intention is as low as $8.7 \%$ (Global Entrepreneurship Monitor, 2010).

The rising issues in unemployment rate among graduate students that were increase from year to year also leads to discover on this research. This latitude become more crucial since Malaysian Government rises the mandatory retirement age for pension that makes the fresh graduates face a bleak future as the government is the biggest employer in the nation. A study conducted by Ministry of Education Malaysia's Graduate Tracer Study in 2018 has reported that nearly $60 \%$ remain unemployed one year after graduation. This could affect the graduates' future as they are unable to find the suitable or right career path according to their academic qualification. Keat et al. (2011) said that today's job for fresh students are limited because competitive job environment, total job opportunities and thus one must compete to secure a job supply of jobs is limited.

In order to overcome this problem and to decrease the percentage of unemployment rate, students have to choose self-employed and create new opportunities that could generate income to them. Most of the students have interest and potential in their self about being entrepreneur, but they are lack of exposure to the real business world. Therefore, this study attempts to examine the relationship between role model, family background, also the entrepreneurship curriculum and content towards entrepreneurship inclination among the students.

\section{Literature Review \\ Entrepreneurial Inclination}

Kim (2008) affirmed that defining entrepreneurship and entrepreneur is a difficult task to do. Whereby, inclination or propensity can be defined as a person' natural tendency or urge to act or feel in a particular way. Inclination of students in business is when they are naturally want to involved in business world and make or create job for them self. Most of the students that involved in the businesses see that the career could provide more profits to them. Most of the researchers agree that entrepreneurship is a vital route to economic advancement for developed and developing economies in this world (Zelealem et al., 2004).

In extension from Kobia et al. (2010), much of this interest is driven by students' demand for courses in entrepreneurship, either because students see entrepreneurship education as a 
useful edge given uncertain corporate career or they are interested to study the topic. Some of the researchers identified the need for all undergraduate students to develop an enterprising knowledge, mindset, experience, creative thinking, confidence, social and communication skills as part of their degree program and it will help them in the future.

\section{Role Model}

Role model can be defined as a person whose behavior that can be emulated by others, especially by younger people. In consonance with Hisrich et al. (2005), role models are "individuals influencing an entrepreneur's career style or choice". It appears that role model can make and entice other people to follow what they are doing. The person became something that other people wants to be. Therefore, to influence a student to become an entrepreneur, we must find someone who is successful in doing business that hopefully will make them enticed to be an entrepreneur. As an example in Malaysia, Noor Neelofa Mohd Noor or popularly known as Neelofa is a stunning actress, television presenter and a successful Muslim entrepreneur as she become a millionaire at the age of 27 .

Role models for entrepreneurs is an evidence of popular and success business press that is littered with stories of, and references to, entrepreneurial effort and successes that have influenced other entrepreneurs in this world (Bosma et al, 2012). Some of the self-employment criterion involves business ownership, where entrepreneurship is considered as having the organizational status as legally owning a business (Thurik et al., 2008). Djankov et al. (2005) claimed that in Russia, amongst other factors, role model is one of the factors that has an effect on entrepreneurial activities in that country. Moreover, some of the interesting and important things that someone who is in close contact with an entrepreneurial role model is more likely to develop the desire and confidence to create their own business in future. A role model and idols can be so influence in directing the society tendencies to be success and innovative in making their job.

Conferring to the European Commission's Green Paper on entrepreneurship, it will be more success by "providing role-models through the "show casting' of success stories" as an essential tools for the promotion of an entrepreneurial culture and positive attitudes towards entrepreneurship (European Commission, 2003). A part from that, entrepreneurial role models may experience changes in terms of societal valuation, which could lead to an increase in the society's motivations to engage in entrepreneurial activities. Hence, the role model will positively influence and encouraging specific career path to the self-efficacy of individuals to become stronger and more creative in their entrepreneurial works.

\section{Family Background}

It cannot be denied, that family involvement in business tends to influence the children to be involved in business too. Tong et al (2011) noted that by stressed out the perspective that said the important factor which is family business student background (FBB) will lead the students to started new business in future. Other researchers also mentioned that students or person that born with business background will have higher chances to involve in entrepreneurial activities in future. In corresponding to gender, Nor et al (2004) aforesaid that the most of the previous studies have found that females are less inclined towards entrepreneurship than males. In some previous research, the finding identifies there is a significant relationship on the demographic variables that are not only give impact on GDP, investment and inflation (Aksoy et al, 2012), but also impact on family (Bianci, 2004). Examples of the demographic characteristic that have been conducted in the past research are gender, religion, age, birth order, area of living, courses, 
ethnicity, working experiences and family background influences. Based upon the previous research, the results showed that the study particularly controlled the university students' demographic characteristics and family business background (Keat et al., 2011). Moreover, people who had bigger family size will have more tendency to involved in entrepreneurship such as family that have 7 or more members were 1.768 times more likely to involve in entrepreneurship compared with family who had fewer than three people in the family (Sharma, 2014).

Yusop (2002) also cited that most of the past studies found significant relationship between family background and inclination towards entrepreneurship. People that came from business background will influence and motivate their siblings and others to involve in entrepreneurial activity and they are expected to possess higher inclination to launch a business in future. In terms of household gender role, fathers have higher self-employment than mothers to influence on their children's decisions to become entrepreneurs. Thus, the impact of parental or family experience has been found to be depending on the perception of the students of their parents' or relatives' experience of business ownership as a success or failure (Boissin et al., 2008).

\section{Entrepreneurship Curriculum and Content}

Entrepreneurial educations at tertiary level become a predominant component of many curriculums in public and private higher learning institutions (Kamsol Mohamed Kassim et al, 2009). Edwards et a (2005) also expressed that different universities will develop differences entrepreneurial curriculum, either as an optional module within business courses or a specific course on entrepreneurship. The objectives of entrepreneurship education are aimed to transpose students' state of behaviors and intention that would make them understand about entrepreneurship knowledge as well as to form a new businesses as well as new job opportunities (Fayolle \& Gailly, 2005). In attaining this, Robinson \& Haynes (1991) point out that the most importantly is "tying academic learning to the real world". Curriculum development is a pivotal educational process for educational developers for schools or college, further education (FE) and higher education (HE) as it allows an educational course to be designed to meet defined needs. The entrepreneurship educations and contents that have been thought in the class should contributes to the student development in progressing to become entrepreneur. Studies on entrepreneurship education in Malaysia by Ismail et al. (2010) found that the current practices is ineffective in matching students' skill expectations with their skill acquisition and therefore, a new approach is demanded.

Entrepreneurship education should able to grant the students the understanding about business practices and environment. The entrepreneurship education and awareness programs that focus on general knowledge about entrepreneurship are able to encourage participants to think that entrepreneurship as a career and work. The pronouncement from Nabi et al. (2006) mentioned that graduate entrepreneurship as the interrelations between a graduate of university educations and the attitude towards a work choice of self-employment or business-start up. Besides that, the entrepreneurship course is one of the centered ways to produce students who are able to deal with real entrepreneurial activities or to transform students' entrepreneurial competencies (Keat et al., 2011). Students will be more attracted to be entrepreneur when they are exposed to the entrepreneurship course and study in detail about the subject. Cheung (2008) mentioned that there are more jobs or work available even when technology is advanced in future that creates job without boundaries. All these aspects would increase the number of smallto-medium-sized entrepreneurs. 


\section{Research Objectives}

Based on the above review of literatures, this study aims to achieve the following objectives:

- To determine the relationship of role model, family background and entrepreneurship curriculum and content among the undergraduate students' inclination towards entrepreneurship.

- To determine the most predictive power of each variable on the students' inclination towards entrepreneurship.

\section{Research Framework}

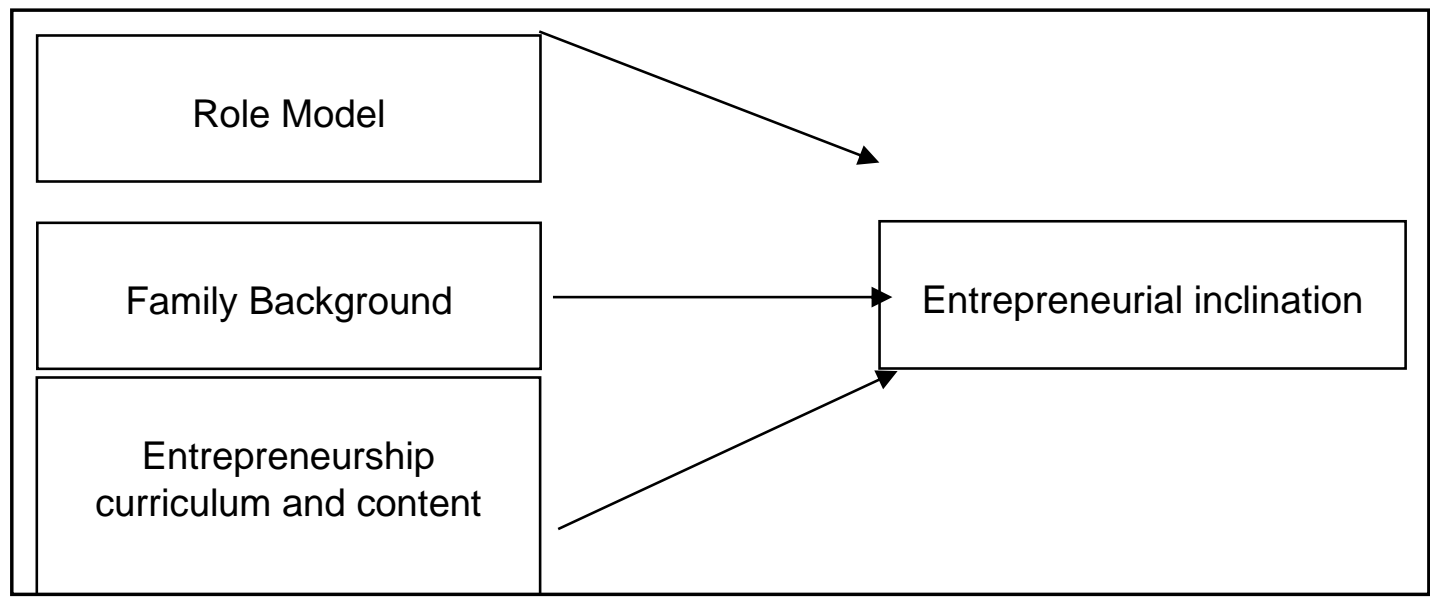

Figure 1 Theoretical Framework

(Sources: Keat et al., 2011 \& Zegeye, 2013)

\section{Research Methodology}

This study focused on students of Business and Management Faculty in Higher Learning Institution to identify their attentiveness towards entrepreneurship in their life. Using convenience sampling technique, the sample was chosen from a few public universities in Northern Region Malaysia that involved 171 students. The respondents were chooses among undergraduate students, starting semester one until six. Most of the respondents were taking Marketing, Human Resource Management and Finance programs since they are accommodate with entrepreneurship course. At the date of data collection, Malaysia is still under Movement Control Order (MCO). Hence, the survey was done via online that encompasses of two languages which are English and Malay to accommodate respondent's preference. This study utilized questionnaires adapted from Keat et al., 2011 and $\mathrm{Ni}$ et al. (2012). The research instrument consists of five sections with 32 items including demographic. To measure the items, Likert scale of 1 to 5 (from the lowest value of 1 indicate to "strongly disagree" and the largest value of 5 indicate to "strongly agree") were used to collect information on the study variables.

\section{Findings Analysis}

Table 1 showed that the response rate is $83 \%$ of sample size (171 students). Among those who participated, $71.9 \%$ is female and most (93\%) of the respondents are in the range of 22-25 years old. Apparently, there is slightly different between areas of living among the respondents which reported $56.1 \%$ lives in city area, where as $43.9 \%$ in rural area. The reliability of the questionnaire ranges from 0.8-0.9 which indicates that they are appropriate 
for use (Nunnaly, 1978). The mean value for all dimensions shows that most respondents agree with the statements offered in the questionnaire. Table 2.0 depicts the alpha value and mean for each of the sections.

Table 1 Demographic of Respondents

\begin{tabular}{llcc}
\hline Variables & Categories & Frequency & Percentage (\%) \\
\hline Gender & Male & 48 & 28.10 \\
& Female & 123 & 71.90 \\
\hline Age & $18-21$ years old & 8 & 4.70 \\
& $22-25$ years old & 159 & 93.00 \\
& 26-29 years old & 4 & 2.30 \\
\hline Area of living & City & 96 & 56.10 \\
& Rural & 75 & 43.90 \\
\hline
\end{tabular}

Table 2 Reliability Analysis

\begin{tabular}{lccc}
\hline \multicolumn{1}{c}{ Variables } & No. of items & Cronbach's Alpha & Mean \\
\hline Entrepreneurship Inclination & 8 & 0.832 & 4.12 \\
Role Model & 6 & 0.916 & 3.83 \\
Family Background & 5 & 0.940 & 4.12 \\
Curriculum and Content & 9 & 0.932 & 4.34 \\
\hline
\end{tabular}

In order to achieve the researcher's objectives of investigating the relationship between role model, family background and curriculum \& content with entrepreneurship inclination, the data were analyzed using Pearson Moment Correlations. The results showed that there is a significant relationship between each of the variables with the dependent. However, the strength of the relationship is differed. Thus, the relationship between role model and entrepreneurship inclination, it is moderate $r=0.62$ at $99 \%$ significant level. Similar results is discovered with the relationship between curriculum \& content with dependent variable, the relationship is also moderate $(r=0.68, p=0.01)$. Meanwhile, for the relationship between family background and entrepreneurship inclination, the strength is high at 0.80 . All variables are also found to be significantly correlated with each other. The information is summarized in Table 3.0.

Table 3 Correlation Analysis

\begin{tabular}{lcccc}
\hline \multicolumn{1}{c}{ Variables } & RM & FB & CC & EIC \\
\hline Role Model & 1 & & & \\
Family Background & .061 & 1 & & \\
Curriculum and Content & $.57^{* *}$ & $.67^{* *}$ & 1 & \\
Entrepreneurship Inclination & $.62^{* *}$ & $.80^{* *}$ & $.68^{* *}$ & 1 \\
\hline
\end{tabular}

Next, a multiple regression test in Table 4 was conducted in order to understand the predicted power of the factors that effects entrepreneurship inclination. The result shows the adjusted $r^{2}$ is 0.68 , with a different weightage of the standardized coefficient. All variables and positively affected on dependent variable. The results were supported by previous study conducted by Keat et al. (2011), Zegeye B. (2013) and other researchers. Thus, universities should provide "entrepreneurial environment" in order to encourage entrepreneurial culture 
among students, besides continuous development of curriculum and content that meet industries' demands.

Table 4 Multiple Regression Analysis

\begin{tabular}{lcl}
\hline \multicolumn{1}{c}{ Variables } & $\beta$ & Sig. \\
\hline Role Model & .15 & .001 \\
Family Background & .55 & .000 \\
Curriculum and Content & .22 & .000 \\
Adjusted R Square & .68 & \\
\hline
\end{tabular}

\section{Discussions}

The results of the findings indicate that role model, family background, and curriculum and content were significant and positively influence the entrepreneurship inclination among Business Management students' in Higher Learning Institutions. Role models have been used as the entrepreneurship support policies as a tool to help stimulate entrepreneurial behavior. Someone who has close contact with an entrepreneurial role model is more likely to develop the desire and confidence to create their own business in future and they are having high tendencies become more successful and innovative person. The result was supported by Gibson (2004) who draws on theories of social learning and role identification; the role models can generally serve three interrelated functions which are to provide learning process, to assists individuals define their self-concept and to provide motivation and inspiration. Besides that, Zellweger et al (2011) have discovered that role models and particularly parental role models to positively contribute to an inclination to undertaken entrepreneurial career or job. People that have high level of education may have more ambitious goals based on the examples and support by role model since educated role model may provide more information and benefits. Individuals also are urged to seek role models who can help them in achieving their goals (Lockwood et al., 1997), but also leaders of company are in turn urged to be role models for their employees (Deal et al., 1982).

This study also found a strong relationship between family background and entrepreneurial inclination. This is the most predictive power compared to other variables. The result was supported by Zageye (2013) that students who own a family business have higher inclination towards entrepreneurship. Sharma (2014) stated that students in developing countries are either earning part time to generate some money to support them or their families for their education and other uses of money, the role of families become even more important in career intent especially in taking up entrepreneurship as a career option. Besides that, from a study by Cetindamar et al (2012) mentioned that family capital can be beneficial in facilitating individual's entrepreneurial entry.

Some people may think that entrepreneurship curriculum and content is not important to learn in venture into new business. This is an erroneous believes since the independent shows a significant relationship towards the inclination of entrepreneurial. The research finding was supported in previous study conducted by Borgese (2010) found the course content that related to communication and interpersonal skills, financial, marketing management and business foundations were considered the most significant. In development of a curriculum and content, the cyclic process comprising of four stages or steps which are, first identification of needs, followed by design of a course of study, delivery of the learning program and the evaluation of the outcomes in relation to the initial objectives. Thus, the 
entrepreneurship courses must be revised over time in order to suit the demand and global rapid changes in business.

\section{Conclusions}

In a nutshell, this study found that role model, family background, and curriculum and content have a significant relationship with entrepreneurial inclination as perceived by the students of Higher Learning Institutions. Based on the above discussion, it can be concluded that universities may assist students to become a successful entrepreneur through hands on projects that could spurs curiosity by giving the opportunities to open real legitimate business and facing the real life business environment. It is recommended that a module that warranted the student form an enterprise and try to innovate and sell their own products as part of the group projects assignment. In the rubrics, marks will be evaluated and serve as continuous assessment for the whole semester. It is not about the success of getting sales or closing deals, but more towards self-reflection of the exposure them to the real business world. In such a way the student will gain some valuable experience in the processing of setting up new venture.

As part of realizing the role model, university should invite business executives, successful Small and Medium Enterprise (SME) entrepreneurs' to engage with the universities and perhaps giving hands on lecture on specific entrepreneurship topics and deliver a presentation or sharing experiences. The role can be extended by appointed them to become consultant and mentor to the students. Assistant and aids should be given to the student to launch the new business. The development of the content has to undergo tremendous changes by offering certain platform of facilities advisory activities that will foster innovative thinking breakthrough. Thus, the business environment is uncertain and highly ambiguous. Universities must took into account to prepare the student mind-set agility and flexibility in facing the unpredictable world. An incentives scheme policy must be developed in en riching and realizing them to become entrepreneur by giving kick-starter packages and funds, assess of proliferation in range of equipment and facilities, awards and prizes. This encouragement and effort will be the foundation of the university to excel the student in entrepreneurship activities. Even though this study presented that entrepreneurial inclination among students in $\mathrm{HLI}$, but it does not reflect the actual population as a whole. As for that, it is also recommended that future studies include a larger sample to get more accurate explanation in regard to this issue. Inclusion of the private and other public universities as a comparative study could enhance the understanding of this issue. Furthermore, it is also recommended for future studies to identify the differences in gender towards the dependent variable since there is lack of study on this area.

The study contributes to mainstream knowledge intersection of the entrepreneurship development. Today's trend, online business has become the first choice of students in starting a new business. Subsequently, digital entrepreneurship should be embedded in content and syllabus in the university. A business-related using computer platform has become the solution of new business venture. The significant of digital business to the entrepreneurship world is still untrodden and need to be further study and yet the field lacks empirical evidence on the effects towards digital entrepreneurship. It is highly encourage to further explore and to investigate the influence and impact of digital technology and entrepreneurship. 


\section{Acknowledgement}

Since Malaysia is still under Movement Control Order (MCO), researcher would like to thank all respondents for their participation during the collection of data.

\section{References}

Borgese, A. (2010). Educating sports entrepreneurs: matching theory to practice. The Sport Journal, 13(3).

Cheung, C. K. (2008). Practicing entrepreneurship education for secondary pupils through the operation new year stall in Hong Kong. Asia-Pacific Education Researcher, 17(1), 15-31. doi: 10.3860/taper.v17i1.347

Deal, T. E., and Kennedy, A. A. (1982) Corporate Cultures: The Rites and Rituals of Corporate Life. Addison Wesley Publishing Company, Reading, 126.

Edwards, L. J., and Muir, E. J. (2005). "Promoting entrepreneurship at the University of Glamorgan through formal and informal learning." Journal of Small Business and Enterprise Development 12(4): 613-626.

Fayolle, A. G., and Gailly, B. (2005). Using the Theory of Planned Behaviour to assess entrepreneurship teaching programmes, Centre for Research in Change, Innovation and Strategy: 1-18.

Gibson, D. E. (2004). Role models in career development: new directions for theory and research. J. Vocat. Behav. 65, 134-156. doi: 10.1016/S0001-8791(03)00051-4

Ismail, A., Abdullah, A. G. K., \& Othman, A. T. (2010). Acceptance of entrepreneurship culture module at the Malaysian institutes of higher learning: A gender perspective. Research Journal of International Studies, 15, 46-54.

Ismail, M., Khalid, S. A., Othman, M., Jusoff, H. K., Rahman, N. A., Kassim, K. M., \& Zain, K. M. (2009). Entrepreneurial intention among Malaysian Undergraduates. International of Business and Management, 4(10), 54-60.

Karimi, S., Biemans, H. J. A., Lans, Th., Chizari, M., \& Mulder, M. (2014). The Impact of Entrepreneurship Education: A Study of Iranian Students' Entrepreneurial Intentions and Opportunity Identification. Journal of Small Business Management - DOI: 10.1111/jsbm.12137

Lockwood, P., and Kunda, Z. (1997). Superstars and me: predicting the impact of role models on the self. J. Pers. Soc. Psychol. 73:91. doi: 10.1037/0022-3514.73.1.91

Ni, L. W., Ping, L. B., Ying, L. Y., Sern, N. H., \& Lih, W. J. (2012). Entrepreneurial Intention: A Study among Students of Higher Learning Institution. Unpublished Undergraduate Thesis, University Tunku Abdul Rahman.

Nunnally, J. C. (1987). Teoría psicométrica. Méjico: Trillas.

Sandhu, M. S., Sidique, S. F., \& Riaz, S. (2011). Entrepreneurship barriers and entrepreneurial inclination among Malaysian postgraduate students. International Journal of Entrepreneurial Behavior \& Research, 17 (4), 428-449.

Zegeye, B. (2013). Factors explaining students' inclination towards entrepreneurship: Empirical study of Ethiopian University Students. Journal of Emerging Issues in economics, Finance and Banking, 1(4), 302-320. 